\title{
Nutritive and Anti-nutritive Evaluation of Cnidoscolus aurifolia Leaves
}

\author{
Akaninyene Uwemedimo Udo ${ }^{1}$, Uwemedimo Emmanuel Udo ${ }^{2}$ \\ ${ }^{1}$ Department of Home Economics, Nutrition and Dietetics, Faculty of Agriculture, University of Uyo, P.M.B. 1017, Uyo, Nigeria. \\ ${ }^{2}$ Department of Chemistry, Faculty of Science, University of Uyo, P.M.B. 1017, Uyo, Nigeria. \\ A R T I C L E I N F O \\ Article history: \\ Received 25 May 2016 \\ Accepted 22 August 2016 \\ Available online, ISSN: 2148-127X \\ Keywords: \\ Antinutrients \\ Cnidoscolus aurifolia \\ Mineral elements \\ Phytochemicals \begin{abstract}
A B S T R A C T
The leaves of Cnidoscolus aurifolia were analysed for their chemical, antinutrients, proximate and mineral element compositions using standard procedures. Phytochemical screening revealed the presence of alkaloids, saponins, flavonoids, terpenes and tannins while anthraquinones, glycosides and phlobatannins were absent. Proximate analysis indicated high protein content $(59.45 \pm 0.07 \%)$ with crude fibre and fat also present in appreciable quantities. Mineral elements determination showed the presence of calcium, iron, magnesium, potassium and zinc. Antinutrient analysis of the leaf extract of $C$. aurifolia indicated low levels of phytic acid and hydrocyanide well below the lethal doses. An unusually high oxalate level of $404.80 \pm 0.11 \mathrm{mg} / 100 \mathrm{~g}$ (dry weight) was also obtained although still below toxic level. These results support the ethnomedicinal and nutritional uses of this plant and suggest that the consumption of leaves of $C$. aurifolia is
\end{abstract} \\ not harmful nutritively.
}

Nutritively

${ }^{*}$ Corresponding Author:

E-mail: uwemedimoudo@uniuyo.edu.ng

\section{Introduction}

Vegetables are edible parts of plants that are consumed wholly or in parts, raw or cooked as part of main dish or salad (Uwaegbule, 1989). The consumption of leafy vegetables as food has remained the cheapest and commonest means of furnishing the body with adequate supplies of proteins, vitamins, minerals, fibre and other nutrients (Akan et al., 2009). The nutritional value of some selected leafy vegetables of sub-Saharan Africa and their potential contribution to human health has been extensively reviewed elsewhere (Aletor and Adeogun, 1995; Uusiku et al., 2010). These findings have given credence to the popular fact that most of these leafy vegetables are good and valuable sources of minerals, proteins, fat and oil.

One of such important edible leafy vegetables is Cnidoscolus aurifolia (family Euphobiaceae) which is commonly served as food in many homes in Nigeria. It is specially prescribed by traditional medicine practitioners to blood-deficient patients with the belief that it is capable of boosting their blood profile. To our knowledge, the proximate composition, levels of minerals, antinutrients of the leaves of Cnidoscolus aurifolia have not been reported despite its widespread use.

In the present study, the phytochemical, proximate, mineral elements and antinutrients profile of the leaves of Cnidoscolus aurifolia from Nigeria have been evaluated using standard analytical methods.

\section{Materials and Methods}

Plant material:The fresh leaves of Cnidoscolus aurifolia were collected from a farmland in Osongama Housing Estate in Uyo Local Government Area of Akwa Ibom State, Nigeria in the month of July 2015. Plant identification, authentication and specimen referencing were done by Dr. Margaret Bassey, a plant taxonomist in the Department of Botany and Ecological Studies, University of Uyo, Uyo, Nigeria. A voucher specimen (UUH 3423) has been deposited at the Herbarium of the Department of Botany and Ecological Studies.

Sample preparation: The leaves of $C$. aurifolia were thoroughly washed with distilled water to remove any trace of dirt sticking to the surface of the leaves. The leaves were chopped into small pieces and air-dried for 14 days. They were later homogenized to fine powder using a mechanical blender (Binatone BLG-402, China) and stored in an air-tight plastic bag, properly labeled prior to analyses.

Extraction procedure: The dried pulverized plant leaves $(450.0 \mathrm{~g})$ were thoroughly macerated with $80 \%$ ethanol $(2.5 \mathrm{~L})$ for 7 days at room temperature. The sample mixture was filtered and the filtrate concentrated using a rotary evaporator at $40^{\circ} \mathrm{C}$ to afford a green colored extract. The extracts were stored in a sealed container and kept in a refrigerator at $4^{\circ} \mathrm{C}$ until use. All reagents and chemicals used in this work were of 
analytical (AnalaR) grade and were sourced from SigmaAldrich chemical company, United Kingdom.

Proximate analyses: These analyses were carried out to determine the moisture, ash, crude fibre, fat, crude protein content in the leaves of Cnidoscolus aurifolia. The moisture content of $C$. aurifolia leaves was determined by drying the leaves in an oven (Gallenkamp OV-330) at $105^{\circ} \mathrm{C}$ until a constant weight was obtained (AOAC, 1990) (method 14:004). The percentage moisture content was calculated from the equation:

$$
\text { Moisture }(\%)=\frac{W_{2}-W_{3}}{W_{2}-W_{1}} \times 100
$$

Where,

$\mathrm{W}_{1}=$ Initial weight of empty crucible,

$\mathrm{W}_{2}=$ Weight of crucible + sample before drying,

$\mathrm{W}_{3}=$ Final weight of crucible + sample after drying

Total ash was determined by Furnace incineration described by AOAC (1990) (method 14:006) using about $1.0 \mathrm{~g}$ of oven-dried sample. This analytical method is based on the vaporization of water and volatiles with burning organic substances in the presence of oxygen in the air to $\mathrm{CO}_{2}$ at a temperature of $550^{\circ} \mathrm{C}$ for 5 hours. The $\%$ ash content was calculated as:

$$
\text { Ash }(\%)=\frac{\text { Weight of Ash }}{\text { Weight of Original Sample }} \times 100
$$

Crude fibre was determined using the method of (AOAC, 1990) (method14:020). The percentage crude fiber was calculated as per the formula:

$$
\text { Crude fibre }(\%)=\frac{\text { Weight after drying }}{\text { Weight of Sample }} \times 100
$$

Crude protein content was calculated by converting the nitrogen content determined by Kjeldahl's method $(6.2 \mathrm{~N})$. Fat was determined by the method described by the AOAC (1990) using the Soxhlet system. The carbohydrate content was estimated as the difference obtained after subtracting the values of the organic protein, fat, ash and fiber from the total dry matter. The calorific value of the sample was obtained by multiplying the values of the crude protein, lipid and carbohydrate by 4, 9 and 4 respectively and taking the sum of the products.

Mineral element analysis: Mineral digestion was done following the method of Egan et al., (1981). The concentrations of calcium, magnesium, iron and zinc were determined using an atomic absorption spectrophotometer (AAS Unicam 919) in conjunction with reference mineral standards from Unicam Limited, United Kingdom. The flame photometer (Jenway Limited, UK) was used for determination of potassium concentration in the extract.

Qualitative determination of phytoconstituents: Qualitative tests to identify the constituents of the extract were performed using standard procedures outlined by Harborne (1984) and Trease and Evans (1996). Precisely, screening of alkaloids was carried Dragendroff's and Mayer's reagents, saponins by Frothing and Fehling's tests. Cardiac glycosides were detected by Liebermann's and Keller-Killiani's tests, tannins by the Ferric chloride test and phlobatannins by hydrochloric acid test. Flavonoids were detected by the magnesium metal/hydrochloric acid test, triterpenes by the chloroform/acetic anhydride/sulfuric acid test and anthraquinones by the benzene/ammonia solution test.

Determination of antinutrient composition: The composition of oxalate was determined using the method outlined by Sanchez-Alonso and Lachica (1987) and hydrocyanic acid by that of AOAC (1990). Phytic acid was determined by the method of McCance and Widdowson (1953). The Folin-Denis Spectrophotometric method described by Pearson (1976) was used for determination of tannins.

Data handling: All analyses were done in triplicate and values were expressed as mean \pm standard error of mean (i.e. Mean $\pm \mathrm{SEM}$ ).

\section{Result and Discussion}

\section{Results}

The result of the qualitative phytochemical analysis of leaf of Cnidoscolus aurifolia is shown in Table 1, while that of mineral element determination is shown in Table 2. The levels of antinutrients and that for proximate composition of the leaf of $C$. aurifolia are shown in Table 3 and 4 respectively.

\section{Discussion}

Phytochemical analysis: The result of phytochemical analysis of leaves of Cnidoscolus aurifolia is given in Table 1. This result indicates the presence of alkaloids, flavonoids, saponins, terpenes and tannins while anthraquinones, cardiac glycosides and phlobatannins were not detected. The medicinal properties of these secondary metabolites are quite numerous and have been well documented elsewhere (David, 1983; Frantisek, 1998; Price et al., 1987; Banso and Adeyemo, 2007 and Akpan et al., 2012). The presence of these bioactive compounds in the leaves of $C$. aurifolia corroborates the various pharmacological activities of this plant and supports its widespread use in traditional medicine.

Mineral element composition: The Mineral element composition of leaves of Cnidoscolus aurifolia is given in Table 2. This result indicates $C$. aurifolia leaves to be a cheap source of calcium, magnesium, potassium, iron and zinc. The calcium content was found to be $96.30 \mathrm{mg} / 100$ g. This value is comparable to $100 \mathrm{mg} / 100 \mathrm{~g}$ earlier reported for Indian Solanum tubirosam (Okaka et al., 2006) and $101 \mathrm{mg} / 100 \mathrm{~g}$ in Vietnamese Ipomea aquatia leaves (Ogle and Grivetti, 1985). The iron content was estimated to be $34.10 \mathrm{mg} / 100 \mathrm{~g}$. The concentration of iron in C. aurifolia leaves is quite comparable to $34.92 \mathrm{mg} / 100$ $\mathrm{g}$ reported for Telfairia occidentalis leaves grown in South West Nigeria (Asaolu et al., 2012) but lower than $156 \mathrm{mg} / 100 \mathrm{~g}$ reported for Anisorus mannii (Aliyu et al., 2009). The magnesium content of $C$. aurifolia leaves was found to be $63.50 \mathrm{mg} / 100 \mathrm{~g}$. This value is slightly higher than $61.08 \mathrm{mg} / 100 \mathrm{~g}$ reported for veronia amygdalina but lower than that of Gongronema latifolium (92.51 $\mathrm{mg} / 100 \mathrm{~g})$, Ocimium grastissimum $(88.25 \mathrm{mg} / 100 \mathrm{~g})$ and 
Amaranthus hybridus (249.92 mg/100 g) reported by Asaolu et al., (2012). The potassium content in the leaves of $C$. aurifoliawas found to be $98.34 \mathrm{mg} / 100 \mathrm{~g}$ while the zinc content was $17.40 \mathrm{mg} / 100 \mathrm{~g}$. minerals have been reported to play significant roles in many healthpromoting functions within the human body (Aremu and Udoessien, 1989 and Gbolahan, 2001) and thus, consumption of $C$. aurifolia leaves might play useful roles on optimizing their availability and utilization.

Table 1 Contents of phytochemicals in Cnidoscolus aurifolia leaf extract

\begin{tabular}{l|lc}
\hline \multicolumn{1}{c|}{ Phytochemicals } & \multicolumn{1}{|c}{ Test/reagents } & Detection \\
\hline Alkaloids & $\begin{array}{l}\text { Dragendroff's } \\
\text { Mayer's }\end{array}$ & $\begin{array}{c}\text { Present } \\
\text { Present }\end{array}$ \\
\hline Anthraquinones & Benzene/ammonia solution & Absent \\
\hline Flavonoids & Magnesium metal, HCl & Present \\
\hline Cardiac glycosides & Liebermann's & Absent \\
& Keller-Killiani's & Absent \\
\hline Phlobatannins & HCl acid solution & Absent \\
\hline Saponins & Frothing & Present \\
\hline Tannins & Fehling's & Present \\
Terpenes & Ferric chloride solution & Present \\
Protein & Chloroform, $\mathrm{H}_{2} \mathrm{SO}_{4}$ acid & Present \\
Carbohydrate & Biuret solution & Present \\
\hline
\end{tabular}

Table 2 Levels of mineral elements in Cnidoscolus aurifolia leaf extract

\begin{tabular}{l|c}
\multicolumn{1}{c|}{ Minerals (mg/100 g DW) } & Mean \pm SEM \\
\hline Calcium & $96.30 \pm 0.00$ \\
Iron & $34.10 \pm 0.03$ \\
Magnesium & $63.50 \pm 0.03$ \\
Potassium & $98.34 \pm 0.02$ \\
Zinc & $17.40 \pm 0.01$ \\
\hline
\end{tabular}

Values are mean \pm SEM calculated as $\mathrm{mg} / 100 \mathrm{~g}$ dry weight analysed individually in triplicate.

Table 3 Levels of antinutrients in Cnidoscolus aurifolia leaf extract

\begin{tabular}{l|c}
\hline Antinutrients $(\mathrm{mg} / 100 \mathrm{~g}$ DW) & Mean \pm SEM \\
\hline Hydrogen cyanide & $0.32 \pm 0.00$ \\
Oxalate & $404.80 \pm 0.50$ \\
Phytate & $6.67 \pm 0.01$ \\
Tannin & $0.21 \pm 0.01$ \\
\hline
\end{tabular}

Values are mean \pm SEM calculated as $\mathrm{mg} / 100 \mathrm{~g}$ dry weight analysed individually in triplicate.

Table 4 Results of proximate composition of Cnidoscolus aurifolia leaf extract

\begin{tabular}{l|c}
\hline \multicolumn{1}{c|}{ Parameter } & Mean \pm SEM \\
\hline Moisture content (\%) & $12.24 \pm 0.02$ \\
Ash (\%) & $6.64 \pm 0.04$ \\
Crude fibre (\%) & $11.80 \pm 0.08$ \\
Crude fat (\%) & $7.60 \pm 0.11$ \\
Carbohydrate (\%) & $2.27 \pm 0.01$ \\
Crude protein $(\%)$ & $59.45 \pm 0.07$ \\
Calorific value (Kcal/KJ) & $315 / 1320$ \\
\hline
\end{tabular}

Each value represents mean \pm SEM of three determinations on dry weight (DW) basis.
Antinutruent composition: Levels of hydrogen cyanide, oxalate, phytic acid and tannins in the ethanol extract of Cnidoscolus aurifolia are given in Table 3 . The content of hydrogen cyanide $(0.322 \mathrm{mg} / 100 \mathrm{~g})$ was far below the lethal dose of $35 \mathrm{mg} / 100 \mathrm{~g}$ (Munro and Bassir, 1969). Also, the quantity of total oxalate in the extract (404.80 mg/100 g DW) was below the toxic level of 2-5 $\mathrm{g} / 100 \mathrm{~g}$ (Onwuka, 2005) although its value was unusually high. This value is higher when compared to $10.0 \mathrm{mg} / 100$ $\mathrm{g}$ obtained for older leaves of Telfairia occidentalis (Akwaowo et al., 2000). An unusually high oxalate content of $308 \mathrm{mg} / 100 \mathrm{~g}$ has also been reported for Ipomea batatas leaves (Antia et al., 2006). Oxalates are known to complex with calcium to form calcium crystals which get deposited as stones which are associated with blockage of renal tubules (Banso and Adeyemo, 2007). However, processing methods such as proper cooking of the leaves are known to significantly reduce total oxalate content in vegetables (Akwaowo et al., 2000). Based on our investigation, it could be safely speculated that the danger of toxicity associated with the relatively high oxalate content in the plant under study could be significantly reduced by properly cooking the $C$. aurifolia leaves before consumption. Contents of tannins and phytic acid were found to be low.

Proximate composition: The proximate composition of the leaves of $C$. aurifolia is given in Table 4. These results show a protein content of $59.45 \%$ which is quite appreciable. This makes $C$. aurifolia a rich protein source. The moisture content was found to be $12.24 \%$, while ash content was $6.64 \%$. Crude fibre level was found to be $11.80 \%$ while the crude fat content was found to be $7.60 \%$. Lipids provide very good sources of energy and aids in transport of fat soluble vitamin, insulates and protects internal tissue and contribute to important cell processes (Pamela et al., 2005). The level of carbohydrate present in the leaves of $C$. aurifolia $(2.27 \%)$ quite was low and the calorific value was found to be $1320 \mathrm{KJ}$.

\section{Conclusion}

The result of this study has shown that the leaves of Cnidoscolus aurifolia contain an appreciable amount of protein, fibre and fat in addition to some mineral elements. The amount of carbohydrate was low. The low levels of anti-nutrients suggest that the consumption of leaves of $C$. aurifolia is not harmful nutritively and therefore not expected to produce any adverse health effects. The presence of some phytochemicals supports the ethnomedicinal use of this plant in treatment of diseases. This study therefore concludes that $C$. aurifolia leaves can contribute significantly to the human nutritional requirements while also offering adequate protection against diseases.

\section{References}

Akan J, Abdulrahman F, Ogugbuaja V, Ayodele J. 2009. Heavy metals and anion levels in samples of vegetable grown within the vicinity of Challawa Industrial areas, Kano State, Nigeria. American Journal of Applied Sciences 6 (3): 534-542. http://thescipub.com/html/10.3844/ajassp.2009.534.542 
Akpan MM, Odeomena CS, Nwachukwu CN, Danladi B. 2012. Antimicrobial assessment of ethanol extract of Costus afer leaves. Asian J. Plant Sc. Research 2 (3): 335-341.

Akwaowo EU, Ndon BA, Etuk EU. 2000. Minerals and antinutrients in fluted pumpkin (Telfairia occidentalis Hook f.) Food Chemistry -Analytical, Nutritional and Clinical Methods Section 70 (2): 235-240. http://dx.doi.org/10.1016/S0308-8146 (99)00207-1

Aletor VA, Adeogun OA. 1995. Nutrient and antinutrient components of some tropical leafy vegetables. Food Chemistry 53 (4): 375-379.http://dx.doi.org/10.1016/0308-8146(95)99830.

Aliyu AB, Musa AM, Sallau MS, Oyewale AO. 2009. Proximate composition of mineral elements and anti-nutritional factors of Anisopus manni N. E. B. (Asclepiadaceae). Trends Applied Sci. Res. 4 (1): 68-72.http://dx.doi.org/10.3923/tasr.2009.68.72

Antia BS, Akpan EJ, Okon PA, Umoren IU. 2006. Nutritive and anti-nutritive evaluation of sweet potatoes (Ipomoea batatas) leaves. Pakistan Journal of Nutrition 5 (2): 166168.http://dx.doi.org/pjn.2006.166.168

AOAC. 1990. Official methods of analysis. 15th Edition, Helrich, K. (ed) Association of official analytical chemists, Washington DC, USA.

Aremu CY, Udoessien EI. 1989. Chemical estimation of some inorganic elements in selected fruits and vegetables. Food chemistry 37: 227-234.

Asaolu SS, Adefemi OS, Oyakilome Ajibulu IG, Asaolu MF. 2012. Proximate and mineral composition of Nigerian leafy vegetables. Journal of Food Research 1 (3): 214-218.DOI: http://dx.doi.org/10.5539/jfr.v1n3p214

Banso A, Adeyemo SO. 2007. Evaluation of antimicrobial properties of tannins isolated from Dichrostachys cinerea. African Journal of Biotech. 6(15): 1785-1787. http://dx.doi.org/10.5897/AJB2007.000-2262 ISSN: 1684-5315

David H. 1983. The new holistic herbal.3rd Edition.Findhorn press, USA, p. 241.

Egan H, Kirk RS, Sawyer R. 1981. Pearson's chemical analysis of food.8th edition, Churchill Livingstone, Edinburg, United Kingdom, p. 24.

Frantisek S. 1998. The natural guide to medicinal herbs and plants. Tiger book international, plc, Twickers, London, pp 8-20.
Gbolahan D. 2001. Lesson note on medicinal importance of trace elements, centre for natural health studies, Surulere, Nigeria, p. 67.

Harborne JB. 1984. Phytochemical methods, 2nd edition, champman and Hall, London. pp.20-22. DOI:10.1007/978-94009-5570-7Print ISBN978-94-010-8956-2

McCance RA, Widdowson EM. 1953. Phytin in human nutrition. Biochemic J. 29 (12):2694-2699.PMCID: PMC1266816

Munro A, Bassir O. 1969. Oxalate in Nigerian vegetables. W. A. J. Biol. Appl. Chem. 12:14-17.

Ogle BM, Grivetti LE. 1985. Legacy of the chameleon: Edible wild plants in the Kingdom of Swaziland, Southern Africa. A cultural, ecological nutritional study.Part IV: Nutritional analysis and conclusion.Ecol. Food Nutr. 17: 41-64.

Okaka JC, Akobundu EN, Okaka CA. 2006. Food and nutrition, an integrated approach. O. J. C. Academic Pub. Enugu. Nigeria

Onwuka GI. 2005. Food analysis and instrumentation: theory and practice. Naphtalic prints, Surulere, Lagos. Nigeria, pp. 219230.

Pamela CC, Richard AH, Denise RF. 2005. Lippincotts illustrated reviews in biochemistry. 3rd edition, Lippincott Williams and Wilkins, Philadelphia, pp. 335-388. ISBN-13: 978-1451175622

Pearson D. 1976. Chemical analysis of foods.(7th Ed), Henry Edward company, Churchchill, Livingstone, London pp. 218336.

Price KR, Johnson IT, Fenwick GR. 1987.The chemical and biological significance on saponins in food and feeding stuffs.CRC Crit. Rev. Food Sci.Nutr. 26(1):27-135. PMID: 3308321

Sanchez-Alonso F, Lachica M. 1987. Seasonal trends in the elemental content of plum leaves. Commun. Soil Sci. Plant Anal. 18:31-43.DOI:10.1080/00103628709367801

Trease GE, Evans WC. 1996. Pharmacognosy. Thirteen edition, Balliere Tindall, London, p.882.

Uusiku NP, Oelofse A, Duodu KG, Bester MJ, Faber M. 2010. Nutritional value of leafy vegetables of sub-Saharan Africa and their potential contribution to human health: A review. J. Food Comp. Anal. 23 (6):499-509.DOI: 10.1016/j.jfca.2010.05.002

Uwaegbule AC. 1989. Vegetables: Nutrition and utilization. In: Food crops production. Dotanpublishers Ltd. Ibadan, pp. 39-44. 